\begin{tabular}{|l|l|l||}
\hline \multicolumn{2}{|c|}{ PublisherInfo } \\
\hline \hline PublisherName & $:$ & BioMed Central \\
\hline \hline PublisherLocation & $:$ & London \\
\hline \hline PublisherImprintName & $:$ & BioMed Central \\
\hline \hline
\end{tabular}

\title{
Promega wins Taq patent round
}

\begin{tabular}{|l|l|l||}
\hline \multicolumn{2}{|c|}{ ArticleInfo } \\
\hline \hline ArticleID & $:$ & 4737 \\
\hline \hline ArticleDOI & $:$ & $10.1186 /$ gb-spotlight-20030401-02 \\
\hline \hline ArticleCitationID & $:$ & spotlight-20030102-03 \\
\hline \hline ArticleSequenceNumber & $:$ & 89 \\
\hline \hline ArticleCategory & $:$ & Research news \\
\hline ArticleFirstPage & $:$ & 1 \\
\hline \hline ArticleLastPage & $:$ & 3 \\
\hline \hline & & RegistrationDate : 2003-4-1 \\
\hline ArticleHistory & $:$ & OnlineDate \\
\hline \hline ArticleCopyright & $:$ & BioMed Central Ltd2003-4-1 \\
\hline \hline ArticleGrants & $:$ & \\
\hline \hline ArticleContext & $:$ & 130594411 \\
\hline \hline
\end{tabular}




\section{Peg Brickley}

Email: pegbrickley@hotmail.com

A long-awaited decision on rights to the DNA-copying enzyme Taq polymerase was issued yesterday by a split federal appellate panel that handed an uncertain victory to Promega Corp.

The case, which has rolled around in the courts for more than ten years, could at some point hit many molecular biologists in the budget. Taq polymerase is crucial to polymerase chain reaction (PCR) technology, which allows quick DNA replication. Promega has succeeded in holding claims for royalties from Swiss giant Roche Corp. at bay while this case worked through the courts.

Should Roche prevail, prices for the widely used enzyme are likely to rise.

For now, the case is headed back to a federal court in California. The appellate court wants trial Judge Vaughn Walker of the US District Court, Northern California, to take another look at the 1999 ruling in which he found that scientists cheated to land the US patent on the use of Thermus aquaticus, or "Taq," polymerase, for PCR.

Like Walker, the appellate court found a brand of fraud called "inequitable conduct" in Cetus Corp.'s effort to land the patent it later sold to Roche. Promega says Cetus scientists knew they did not have a novel compound when they won patent protection for TaqPCR, but hid the flaws in the scientific underpinnings of the patent.

It is now up to Walker to determine whether the fraud was serious enough to strip Roche of rights to enforce the patent against Promega. Researchers get a PCR license either directly, or by buying an enzyme from a supplier who has licensed the technology for that use. Promega had a license from Cetus for non-PCR use of Taq, but challenged Roche's right to enforce the patent when Roche sued over PCRrelated sales.

In the early years of the case, Roche said 200 scientists who had published research using Promega's Taq were patent infringers. After Walker's first ruling, back in 1999, other firms began selling unlicensed Taq polymerase, as well.

Promega said yesterday's ruling was good news, and that the appellate panel had affirmed the trial court's 1999 finding. "We are pleased with the finding by the court of appeals," said a Promega spokesman. "The case will now be remanded to the trial court for a determination of remedies and sanctions."

But others think that Walker could upset his earlier ruling, and allow Roche to collect royalties from Promega for selling Taq to researchers not licensed to use it for PCR.

"The majority of the appellate court found inequitable conduct, but they did not think the trial judge's supporting analysis was sufficiently clear. They remanded it and if he cleans up his reasoning, they may invalidate the patent," said Thomas Saunders, a Boston life sciences patent lawyer who reviewed the decision. 
The legal uncertainty hanging over the US patent has spilled over into a fight in Australia, where the patent court allowed Roche to amend its patent application to get rid of the science that the American court had found problematic.

Federal appellate Judge Pauline Newman dissented, and insisted the science was valid. "This case illustrates the ease of opportunistic challenge to the conduct of experimental science in the patent context," Newman wrote. "My colleagues have distorted the patent process, and the science it supports, into a game of high stakes hindsight that few patents can survive."

Roche Molecular Systems, the Pleasanton, Calif.-based firm responsible for Taq licensing in the US, was unable to comment on the ruling by deadline.

\section{References}

1. Promega Corp., "Taq Patent News", [http://www.promega.com/taqlegal/Default.htm]

2. Roche Corp., [http://www.roche.com/home.htm]

3. Constans A: "Courts Cast Clouds Over PCR Pricing," The Scientist, September 3, 2001. [http://www.the-scientist.com/yr2001/sep/profile_010903.html]

4. Roche Molecular Systems, [http://us.diagnostics.roche.com/about/rms.htm] 